\title{
Analysis of Class Transfer of BPJS non PBI Patients and Affecting Factors in Moh. Anwar General Hospital Sumenep District
}

\author{
Fitri Dwi Cahyani' $^{1}$, Katmini \\ ${ }^{1}$ Health Center Raas Sumenep \\ ${ }^{2}$ Strada Indonesian Institute of \\ Health Sciences
}

Email:

fitridwi@gmail.com

Received : October $4^{\text {nd }} 2021$

Accepted : October $15^{\text {rd } 2021}$

Published : November $27^{\text {th }} 2021$

\begin{abstract}
Insurance or coverage arises because of human needs. Human needs are not limited, but the means of satisfying these needs are limited. One of these human needs is the protection of a sense of security. The need for insurance coverage stems from the desire to overcome uncertainty. The purpose of this study was to analyze the effect of economic status, perception and level of illness vulnerability on public interest in transferring care classes for non-PBI BPJS patients at Moh. Anwar General Hospital Sumenep Regency. The design of this study is an observational quantitative study with a cross sectional approach with the focus of the research directed at analyzing the effect of economic status, perception and level of illness vulnerability on public interest in transferring care classes for non-PBI BPJS patients at Moh. Anwar General Hospital Sumenep Regency. The total population of 134 respondents and a sample of 100 respondents were taken by the Accidental Sampling technique. The findings show that almost half of the respondents haveeconomic status middle class category as many as 42 respondents (42\%).Most of the respondents have a perception of less category as many as 62 respondents $(62 \%)$. Most of the respondents have a high category of disease susceptibility as many as 56 respondents (56\%). Most of the respondents interested in changing BPJS classes as many as 58 respondents $(58 \%)$. Based on the results of the Logistics Regression analysis showed that the p-value $<0.05$ then $\mathrm{H} 1$ was accepted so it was concluded that there was an influence of economic status, perception and level of illness vulnerability on public interest in transferring non-PBI BPJS patient care classes at Moh. Anwar General Hospital Sumenep Regency. It is expected that respondents can understand more deeply related to BPJS Health so that it can be used properly and the amount of installments does not burden the community.
\end{abstract}

Keywords: Economic status, perception, susceptibility, Illness

Copyright (C) 2021 IIK STRADA Indonesia All right reserved.

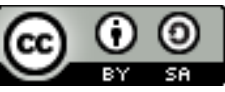

This is an open-acces article distributed under the terms of the Creative Commons AttributionShareAlike 4.0 International License. 


\section{INTRODUCTION}

Every resident in a country needs health protection as a basic need of life. One form of protection is health insurance (Murti, 2007). Efforts to provide health insurance for the population are also carried out by the Indonesian government. This is based on Presidential Decree No. 12 of 2013 article 6 paragraph (1) concerning the National Health Insurance (JKN) which reads that Health Insurance participation is mandatory and covers all Indonesians and the 2019 Universal Health Coverage (UHC) target is that all Indonesians have been registered as members of BPJS Health.

In early 2014, the government began implementing JKN with the aim of making all Indonesians become JKN participants, as a manifestation of universal health coverage (Muninjaya, 2012). The high prevalence of PTM and AKI will result in higher costs of treatment and cure of disease. People who are already protected by health insurance can reduce expenses for medical treatment and healing in health services. Therefore, this program is expected to increase the life expectancy of the Indonesian people and reduce infant and under-five mortality rates, as well as facilitate participants who have other health problems (Thabrany, 2014).

The National Health Insurance is held based on Law Number 24 of 2011 concerning the Social Security Administering Body (BPJS). BPJS Kesehatan on January 1, 2014 began to provide social health insurance to meet the health needs of all Indonesian people who can and cannot afford it. The National Health Insurance is part of the National Social Security System (SJSN) which is implemented in stages by the Health Social Security Administering Body (BPJS). The principle of implementing BPJS is mutual cooperation, mandatory participation, contributions based on the percentage of income wages, non-profit and trustworthy management (Yandrizal \& Utami, 2017).

Based on the 2018 Central Statistics Agency, the population in Indonesia is 261,890,900 million people, while the number of people in Indonesia who have been registered in the National Health Insurance Program is 216,152,549 million people (82\%) as of January 2019. The largest BPJS Health participants are beneficiaries of the assistance. Health Insurance Contribution (PBI) reached 96,637,268 million people. Then participants from Wage Recipient Workers (PPUBU) 24,008,295 million people and Non-Wage Recipient Participants (PBPU) 32,289,326 million people (BPJS, 2019). Based on data from the BPS in 2019 it was stated that the number of people working in Indonesia reached 129.36 million people (BPS, 2019).

Insurance or coverage arises because of human needs. Human needs are not limited, but the means of satisfying these needs are limited. One of these human needs is the protection of a sense of security. The need for insurance coverage stems from the desire to overcome uncertainty. Such uncertainty can pose risks. The risk of uncertainty about illness and the resulting cost implications can be overcome with health insurance covered by health insurance institutions through the health care insurance program. Health insurance turns these events into definite and planned events and helps reduce individual risks (Hendranto, 2014).

Even though BPJS insurance is mandatory, public participation in participating is still very low. Especially in rural and suburban communities. Not everyone can make a decision to join an insurance program even though people know that life is full of uncertainties that will cause risks and losses. Participation in question is influenced by several factors, namely age, education, occupation, income/wealth, gender, lifestyle and population distribution. The same thing was stated by Mulyadi (Maharani, 2014) which states that there are seven factors that influence people to participate in the insurance program, namely age, education, occupation, income, gender, lifestyle and population distribution.

The results of Sakinah, et al. (2014), the level of education and perception plays an important role in a person's high awareness of health insurance because through 9-year compulsory formal education, coupled with high school and higher education, will be able to change the attitudes and behavior of a person or group in carrying out the proper maturity process. continues to increase, so that through the level of education also influences a person in carrying out a planning and control action to overcome an uncertain risk in the future that arises in life.

Several studies in various regions related to community participation to become participants in health insurance, including in a study in Tanzania by Kuwawenaruwa quoted by Pemayun (2015) which stated that the willingness of the community to become participants in health insurance was influenced by gender and socio-economic factors. The socio-economic factors in question are family income, certain groups (women as heads of families), parents, and people with low economic status. 
People with low economic status are not willing to join in health insurance. Another study in Vietnam stated that a person's income, need for health care, age, and level of education are significant determinants that can influence households to be willing to participate in health insurance.

The results of research in China revealed that significant determinants of people's willingness to become participants and pay for health include age, gender, income, past health experience, occupation, vulnerability to illness, and education (Barnighausen in Pemayun, 2015). Another study in Uganda found that on the demand side of health services, information about insurance schemes and their operations, limited understanding of the principles underlying health insurance, and lack of community involvement led to low participation in health insurance. In addition, the lack of trust in the management of the health insurance scheme and the problem of the inability of the community to pay contributions, also affect the low coverage of health insurance (Basaza in Pemayun,

With the existence of classes in BPJS Kesehatan, it is possible that many BPJS Kesehatan participants will switch classes. There are so many cases of inpatients who request to move the class of care from class III to class II or from class II to class I and class I to the Pavilion. Not only patients who go up to class, there are also patients who want to go down from class I to class II and from class II down to class III and there are participants from class III who want to switch to PBI APBD/APBN independently. This is evidenced by the transfer of BPJS Health participants who are in arrears and transferred to the PBI APBD segment as many as 10,784 people in Sumenep Regency.

Based on the above conditions, the authors are interested in researching the analysis of class transfers for BPJS non-PBI patients and the factors that influence it at General Hospital Moh. Anwar, Sumenep Regency.

\section{MATERIALS AND METHODS}

In this study, the researcher used an observational quantitative design with a cross sectional approach, which is a study to study the dynamics of the correlation between risk factors and effects, by approaching, observing or collecting data all at once (point time approach), that is, each subject The study was observed only once and measurements were made on the status of the character or variable of the subject at the time of examination. This does not mean that all research subjects are observed at the same time (Soekidjo, 2012). This research will analyzethe effect of economic status, perception and level of susceptibility to illness on public interest in transferring care classes for nonPBI BPJS patients at General Hospital Moh. Anwar, Sumenep Regency. The total population is 134 respondents and a sample of 100 respondents is taken by the Accidental Sampling technique. Data analysis using Logistic Regression test. This research has conducted an ethical test with the number SK: 2299/KEPK/III/2021.

\section{RESULTS}

Table 1 Results of linear regression analysis analysis of class transfer for BPJS non-PBI patients and the factors that influence it at General Hospital Moh. Anwar, Sumenep Regency conducted by researchers on April 1-30 2021 with a total of 100 respondents

\begin{tabular}{|c|c|c|c|}
\hline No & Variable & Sig & Constant \\
\hline 1 & Economic Status & 0.038 & \multirow{2}{*}{0.012} \\
\hline 2 & Perception & 0.003 & \\
\hline 3 & Sick Vulnerability & 0.036 & \\
\hline
\end{tabular}

1. Economic Status Against Interest

Based on the results of the Logistics Regression analysis shows that the p-value is $0.038<0.05$, then $\mathrm{H} 1$ is accepted so it can be concluded that there is influence economic status on public interest in transferring care classes for non-PBI BPJS patients at General Hospital Moh. Anwar, Sumenep Regency

2. Perception of Interest

Based on the results of the Logistics Regression analysis shows that the p-value is $0.03<0.05$ then $\mathrm{H} 1$ is accepted so it can be concluded that there is the effect of perception on public interest in transferring care classes for non-PBI BPJS patients at General Hospital Moh. Anwar, Sumenep Regency

3. Pain Susceptibility to Interest 
Based on the results of the Logistics Regression analysis, it shows that the p-value is $0.036<0.05$, so H1 is accepted, so it can be concluded that there isthe effect of the level of vulnerability to illness on public interest in transferring care classes for non-PBI BPJS patients at General Hospital Moh. Anwar, Sumenep Regency.

\section{DISCUSSION}

A. Economic Status of the Community in Transferring BPJS Non-PBI Patient Classes at General Hospital Moh. Anwar, Sumenep Regency.

The results showed that almost half of the respondents had economic status in the middle class category as many as 42 respondents (42\%). In addition, 38 respondents $(38.0 \%)$ have economic status in the lower class category. Meanwhile, 20 respondents $(20.0 \%)$ had the economic status of the upper class category.

Humans are developing and active creatures. Humans are referred to as creatures who like to work, humans work to meet their basic needs consisting of clothing, clothing, boards, and fulfill secondary needs such as higher education, vehicles, entertainment equipment and so on (Mulyanto, 2015).

Work will determine socioeconomic status because from work all needs will be fulfilled. Work does not only have economic value but human efforts to get satisfaction and get rewards or wages, in the form of goods and services, will fulfill their life needs. A person's work will affect his economic ability, for that work is a must for every individual because work contains two aspects, physical satisfaction and the fulfillment of life needs. In this regard, Soeroto (2016) provides a definition of work as an activity that produces goods and services for oneself or others, whether people do it for money or not.

Soeroto (2016) explains that by working people will earn income, from the income that the person receives is given to him and his family to consume goods and services resulting from development thus it becomes clearer, whoever is productive, then he has actually participated in real and active in development.

Based on the results of the research and theory above, according to the researcher, the low economy of the people in Indonesia can cause them to be unable to change BPJS Health classes because they do not have the cost to pay more monthly contributions. Most of the rural communities are of lower middle class status whose income is uncertain and still below the UMK standard, so they prefer to meet household needs rather than having to join the BPJS health insurance program which they find burdensome because they have to pay every month.

B. Public Perceptions in Transferring Care Classes for Non-PBI BPJS Patients at General Hospital Moh. Anwar, Sumenep Regency

The results showed that most of the respondents had a perception of the less category as many as 62 respondents (62\%). In addition, a number of 36 respondents (36.0\%) have a perception of the category enough. While a number of 2 respondents $(2.0 \%)$ have a good category perception.

According to the Health Service Use theory from Andersen in the research of Debra et al (2015) states that people's behavior in utilizing health services is determined by the level or degree of illness experienced and the need for health services (perceived need).

The existence of a level or degree of illness that is increasingly felt to be severe, then the individual will increasingly need healing thus the more need for health services, as well as the need for health services, if the higher the need for a service, the higher the desire to take advantage of health services. (Manurung, 2013).

The results of this study are not in accordance with the research of Salma Binti Purwaningsih (2015) which states that people with good knowledge about JKN will consider taking JKN well, while people with less knowledge will take into account JKN because they prioritize their daily needs. rather than following JKN.

According to Parasuraman, Zeithaml and Barry in Qhisti's research (2015), assurance is a guarantee to consumers that includes the ability, courtesy and trustworthiness of the staff, free from danger or risk of doubt, the behavior of employees is expected to foster trust and the company is expected to foster a sense of security for its customers. 
Based on research conducted by Widiastuti (2015) respondents who received contribution assistance from the government (PBI) of $100 \%$ said they were satisfied with health services at puskesmas, possibly because they received contribution assistance from the government. However, for non-PBI BPJS patients or BPJS Mandiri patients, they are very dissatisfied with the services provided where the fees and services can be very disappointing. Where BPJS patients are excluded from general patients.

According to researchers perception is the process of receiving, distinguishing, and giving meaning to the stimulus received by the senses, so that it can draw conclusions and interpret certain objects that it observes. In general, many people initially thought that the existence of BPJS health could help many people, but in the near future many people considered that BPJS was very burdensome for the community and the services obtained at health facilities were also very inadequate. One of the things that burdens the community is the obligation of one family to participate in BPJS health, even though it only requires one member. Thus causing public perception regarding BPJS is very lacking. In addition, because the community views all BPJS classes as the same.

C. The Level of Community Illness Vulnerability in Transferring BPJS Non-PBI Patient Care Classes at General Hospital Moh. Anwar, Sumenep Regency

The results showed that most of the respondents had a high category of disease susceptibility as many as 56 respondents (56\%). While a number of 44 respondents (44.0\%) had a low category of illness susceptibility.

Pain can be interpreted differently based on scientific knowledge and can be seen based on the cultural knowledge of each person with his culture. According to Djekky (2011) scientifically, disease is defined as a disturbance in the physiological function of an organism as a result of infection or pressure from the environment, so the disease is objective. On the other hand, illness is an individual's assessment of the experience of suffering from a disease (Sarwono, 2013).

The range of health and illness according to Neuman (2010) is a client's level of wellbeing at a certain time, which is in the optimal range and condition of well-being, with the maximum energy, until the condition of death which indicates the exhaustion of total energy. So according to this model, health is a dynamic state that changes continuously according to the individual's adaptation to various changes in his internal and external environment to maintain a healthy physical, emotional, intellectual, social, developmental and spiritual state. Meanwhile, illness is a process in which an individual's function in one or more existing dimensions changes or decreases when compared to the individual's previous condition.

The drawback of this model is that it is difficult to determine the client's level of health according to a certain point that is between the two extreme points of the range (high-level wellbeing-death). For example, is someone who has a leg fracture but is able to adapt to limited mobility, is considered less healthy or healthier than someone who has a healthy body but has severe depression. This model is effective if it is used to compare the current level of well-being with the previous level of health. So that it is useful for health workers in determining the goal of achieving a better level of health in the future. The following isHealthy Range of Illness according to the Holistic Health Model (Neuman, 2010).

According to researchers, the susceptibility to illness in a person is the cause of the community's dependence on drugs and health services as a whole. In this case, if a person is often sick, he will often also take advantage of health facilities, and vice versa if a person is rarely sick, he will consume medicines independently rather than using existing health facilities. Based on the results of the study, it was found that many respondents had high disease susceptibility where the disease suffered by the respondents had chronic and seasonal diseases.

D. Public Interest in Transferring Non-PBI BPJS Patient Care Classes at General Hospital Moh. Anwar, Sumenep Regency

The results showed that most of the respondents were interested in changing BPJS classes as many as 58 respondents (58\%). Meanwhile, 42 respondents (42.0\%) are not interested in changing BPJS classes.

Interest is a persistent tendency to pay attention and reminisce about some activity. In other words, interest is a sense of preference and a sense of attachment to a thing or activity, 
without anyone telling. Interest is not only expressed through statements that show a feeling then implemented through active participation in an activity (Saiful, 2012). Interest is a psychological component that plays a role in encouraging someone to achieve the desired goal so that he is willing to carry out activities around the object being observed (Khodijah, 2010).

In simple terms, interest (increat) means a high tendency and excitement / great curiosity about something. Interest is not a popular term in psychology because of its heavy dependence on other internal factors such as concentration, attention, curiosity, motivation, and needs (Reber, 2010). But regardless of popular problems or not, interest can affect the quality of achievement of learning outcomes in certain fields of study.

These results are in line with Juhaini's research (2010) regarding the Potential of Community Participation Towards the Implementation of Health Insurance in the Framework of Universal Coverage in Bandung City. The results showed that most $(94.4 \%)$ of respondents did not have health savings. Furthermore, $87.1 \%$ of respondents stated that they wanted to take insurance. health services with complete health services up to the hospital level. The results of statistical tests obtained $\mathrm{p}$ value $=0.003$, it is stated that there is a relationship between community participation and the Universal Coverage program in the city of Bandung.

According to researchers, interest is persistent tendency to pay attention to and remember some activities. In other words, interest is also a sense of preference and a sense of attachment to a thing or activity, without anyone telling. Interest is not only expressed through statements that show a feeling then implemented through active participation in an activity. Based on the results of the study, it was found that most of the respondents had a high interest in moving to BPJS Health classes, people wanted their health to be guaranteed at all times because of limited costs if they had to carry out general class treatment continuously and also the lack of services that could be obtained when joining lower class membership

E. Influence Economic Status on Public Interest in Transferring Nursing Classes for Non-PBI BPJS Patients at General Hospital Moh. Anwar, Sumenep Regency

Based on the results of the Logistics Regression analysis shows that the p-value is 0.038 $<0.05$, then $\mathrm{H} 1$ is accepted so it can be concluded that there is influence economic status on public interest in transferring care classes for non-PBI BPJS patients at General Hospital Moh. Anwar, Sumenep Regency.

According to Notoatmodjo (2012) factors related to the use of health facilities in this case are BPJS, including knowledge and economic status. A person's economic level will affect the ability to access existing health services.

This result is in line with Littik's research (2015) where the research results obtained factors related to insurance ownership in NTT Province are age (for Jamsostek) with $\mathrm{p}$ value $=$ 0.002 , education level and region (for all types of insurance except JPKM) with value $=0.004$, income (for Askes) with $\mathrm{p}$ value $=0.001$, and distance and transportation (for Askes and Jamsostek) with p-value $=0.001$.

According to research by Ibnu Abdi (2013), it is stated that the large number of family dependents will affect income because the greater the number of family dependents or the number of family members who eat, it will indirectly force the workforce to seek additional income.

Having sufficient income can encourage and be a consideration for someone to become a BPJS Health participant. This is in line with Rohmawati's research (2014) which shows that there is a relationship between income and the choice of the type of contribution $(\rho=0.000)$. Sumardi (2012) suggests that the income received by the population is influenced by the level of education they have. With higher education they will be able to get wider opportunities to get better jobs with greater income. While people with low education will get smaller jobs. Income is one of the supporting factors for a health service.

According to researchers, a person's income level will greatly affect the fulfillment of all needs that must be met by the family. With the existence of a dependent contribution that must be paid by someone for BPJS health insurance every month, it will be quite burdensome for these contributions for families with middle to lower economic status. Moreover, with the increase in contributions, the possibility of people being able to move to a higher BPJS class will be very low. In fact, people will tend to move from the upper class to the lower class. 


\section{F. The Effect of Perception on Public Interest in Transferring Nursing Classes for Non-PBI BPJS Patients at General Hospital Moh. Anwar, Sumenep Regency}

Based on the results of the Logistics Regression analysis shows that the p-value is 0.03 $<0.05$ then $\mathrm{H} 1$ is accepted so it can be concluded that there is the effect of perception on public interest in transferring care classes for non-PBI BPJS patients at General Hospital Moh. Anwar, Sumenep Regency

In early 2014, the government began implementing JKN with the aim of making all Indonesians become JKN participants, as a manifestation of universal health coverage (Muninjaya, 2012). The high prevalence of PTM and AKI will result in higher costs of treatment and cure of disease. People who are already protected by health insurance can reduce expenses for medical treatment and healing in health services. Therefore, this program is expected to increase the life expectancy of the Indonesian people and reduce infant and under-five mortality rates, as well as facilitate participants who have other health problems (Thabrany, 2014).

Insurance or coverage arises because of human needs. Human needs are not limited, but the means of satisfying these needs are limited. One of these human needs is the protection of a sense of security. The need for insurance coverage stems from the desire to overcome uncertainty. Such uncertainty can pose risks. The risk of uncertainty about illness and the resulting cost implications can be overcome with health insurance covered by health insurance institutions through the health care insurance program. Health insurance turns these events into definite and planned events and helps reduce individual risks (Hendranto, 2014).

Even though BPJS insurance is mandatory, public participation in participating is still very low. Especially in rural and suburban communities. Not everyone can make a decision to join an insurance program even though people know that life is full of uncertainties that will cause risks and losses. Participation in question is influenced by several factors, namely age, education, occupation, income/wealth, gender, lifestyle and population distribution. The same thing was stated by Mulyadi (Maharani, 2014) which states that there are seven factors that influence people to participate in the insurance program, namely age, education, occupation, income, gender, lifestyle and population distribution.

The results of Sakinah, et al. (2014), the level of education and perception plays an important role in a person's high awareness of health insurance because through 9-year compulsory formal education, coupled with high school and higher education, will be able to change the attitudes and behavior of a person or group in carrying out the proper maturity process. continues to increase, so that through the level of education also influences a person in carrying out a planning and control action to overcome an uncertain risk in the future that arises in life.

Several studies in various regions related to community participation to become participants in health insurance, including in a study in Tanzania by Kuwawenaruwa quoted by Pemayun (2015) which stated that the willingness of the community to become participants in health insurance was influenced by gender and socio-economic factors. The socio-economic factors in question are family income, certain groups (women as heads of families), parents, and people with low economic status. People with low economic status are not willing to join in health insurance. Another study in Vietnam stated that a person's income, need for health care, age, and level of education are significant determinants that can influence households to be willing to participate in health insurance.

The results of research in China revealed that significant determinants of people's willingness to become participants and pay for health include age, gender, income, past health experience, occupation, vulnerability to illness, and education (Barnighausen in Pemayun, 2015). Another study in Uganda found that on the demand side of health services, information about insurance schemes and their operations, limited understanding of the principles underlying health insurance, and lack of community involvement led to low participation in health insurance. In addition, the lack of trust in the management of the health insurance scheme and the problem of the community's inability to pay contributions, also affect the low coverage of health insurance (Pemayun, 2015).

According to the researcher, the interest in the community to become BPJS members independently in grades 1 or 2 with the full fee charged to all family members is actually high, 
although most respondents have a high interest but this does not cause people to be able to change classes from class. lower class to high class will tend to move to the lower class where this is due to the increase in the value of the monthly contribution even though health services are actually reduced.

G. The Effect of Illness Susceptibility on Public Interest in Transferring Care Classes for NonPBI BPJS Patients at General Hospital Moh. Anwar, Sumenep Regency

Based on the results of the Logistics Regression analysis, it shows that the p-value is $0.036<0.05$, so $\mathrm{H} 1$ is accepted, so it can be concluded that there isthe effect of the level of vulnerability to illness on public interest in transferring care classes for non-PBI BPJS patients at General Hospital Moh. Anwar, Sumenep Regency.

This is in line with Salma's research (2016) which shows that there is a relationship between knowledge and community participation in BPJS Public Health participation $(\rho=0.00)$. Knowledge is the main stage for the community to find out information about the BPJS Health program, the benefits of BPJS Health, as well as the procedures for becoming a BPJS Health participant which will lead to people's motivation in taking an attitude to decide to become a BPJS Health participant. Socialization or dissemination of information on the BPJS Health program can be done in various ways, such as through mass media, social media, counseling, campaigns, word of mouth, and so on (Widyastuti, 2019).

The results of the study on bivariate analysis showed that there was a relationship between socialization about BPJS Health and public interest in BPJS Health participation, the results of the study were proven by statistical tests with a value of $0.000<0.0$ (. This indicates that many people have received information about BPJS Health, information on This is obtained not only through direct socialization but can be obtained through advertisements on television, radio, newspapers and word of mouth information.

This is in line with Nyoman's research (2018) which shows that there is a relationship between socialization and the use of independent National Health Insurance (JKN) $(\rho=0.00)$. Socialization is the main stage for the community to find out information about the BPJS Health program, the benefits of BPJS Health, as well as the procedures for becoming a BPJS Health participant which will motivate the community to take an attitude to decide to become a BPJS Health participant. Socialization or dissemination of information on the BPJS Health program can be done in various ways such as through mass media, social media, counseling, campaigns, word of mouth, and so on (Widyastuti, 2015).

\section{CONCLUSION}

1. Almost half of the respondents have economic status middle class category as many as 42 respondents $(42 \%)$.

2. Most respondents have a perception of less category as many as 62 respondents $(62 \%)$.

3. Most of the respondents have a high category of disease susceptibility as many as 56 respondents $(56 \%)$.

4. Most of the respondents interested in changing BPJS classes as many as 58 respondents (58\%).

5. Exist influence economic status on public interest in transferring care classes for non-PBI BPJS patients at General Hospital Moh. Anwar, Sumenep Regency

6. Exist the effect of perception on public interest in transferring care classes for non-PBI BPJS patients at General Hospital Moh. Anwar, Sumenep Regency

7. Exist the effect of the level of vulnerability to illness on public interest in transferring care classes for non-PBI BPJS patients at General Hospital Moh. Anwar, Sumenep Regency.

\section{SUGGESTION}

1. For Respondents

It is expected that respondents can understand more deeply related to BPJS Health so that it can be used properly and the amount of installments does not burden the community.

2. For Educational Institutions

It is hoped that educational institutions can use the results of this study as learning input in the analysis of transferring classes for BPJS non-PBI patients and the factors that influence it 
at General Hospital Moh. Anwar, Sumenep Regency and can be developed again for further research to be more useful for readers and researchers.

3. For Further Researchers

It is hoped that further research needs to be deepened and added more specific research on the analysis of the transfer of care classes for non-PBI BPJS patients and the factors that influence it at General Hospital Moh. Anwar, Sumenep Regency.

\section{ACKNOWLEDGMENT}

I solemnly declare that to the best of my knowledge, in this thesis there is no scientific work that has been submitted by another person to obtain an academic degree at a university, and there is no work or opinion that has been written or ordered by anyone. others, except those quoted in this manuscript and mentioned in the citation sources and bibliography.

\section{CONFLICT OF INTEREST}

In this study, there is no interest whatsoever regarding myself or with other institutions other than the Indonesian Strada Institute of Health Sciences, Kediri City.

\section{REFERENCE}

BPJS. (2019)Data Kepesertaan BPJS. Akhir Tahun Peserta BPJS Kesehatan. 2015 (diakses 1 Maret 2019). Available from RL: http://www.m. beritasatu.com

Calvin, S. H. dan Gardner, L. (2015) Teori-teori Psikodinamik. Jakarta: Kanisius.

Djuhaeni, H., Gondodiputro, S., \& Setiawati, E.P. (2010) Kesehatan dalam rangka universal coverage di Kota Bandung; 13(03); 140-145.

Elviera, G dan Siwi, P. (2013) Persepsi, Peluang Aksi dan Informasi serta Perilaku Pencegahan Malaria. Jurnal Kesehatan Masyarakat Nasional;7(8);349-353.

Handayani, E. (2013) Faktor-faktor yang mempengaruhi kemauan masyarakat membayar iuran jaminan kesehatan di Kabupaten Hulu Sungai Selatan.

Kementerian Kesehatan RI. (2019) Buku Pegangan Sosialisasi. Jakarta: Kementerian Kesehatan RI.

Peraturan Presiden nomor 109 tahun 2013 tentang Penahapan Kepesertaan Jaminan Sosial.

Praba, I.A.G.R. dan Astiti, D.P. (2014) Peran Persepsi Individu terhadap asuransi dan Model Kepercayaan Kesehatan dalam Pengambilan Keputusan Menggunakan Asuransi Jiwa. Jurnal Psikologi Udayana;1:381-388.

Ramadhana, F. , \& Amir, H. (2015) Persepsi pengusaha dan pekerja UMRM terhadap program jaminan kesehatan sosial nasional.

Sakinah, U. (2014) Faktor-faktor yang berhubungan dengan Kelurahan Poris Gaga Tangerang dalam berasuransi kesehatan. Forum Ilmiah; 11(2):243.

Sarafino, E.P. (2016) Health Psychology: Biopsychosocial Interactions. Fifth Edition. USA: John Wiley \& Sons.

Subari, E. D., Djuhaeni, H., \& Wiwaha, G. (2014) Analisis faktorfaktor yang mempengaruhi intensi menjadi peserta mandiri jaminan kesehatan pada masyarakat Kota Cirebon;(38):1-12.

Tiaraningrum, R. (2014) Studi Deskriptif Motivasi dan Personal Reference Peserta JKN Mandiri pada Wilayah tertinggi di Kelurahan Mojosongo Kota Surakarta. 